\title{
Mapeando a participação política nas Américas e no Caribe: discussão conceitual e aproximações empíricas ${ }^{1}$
}

\author{
Robert Bonifácio \\ Professor Doutor na Universidade Federal de Goiás, Brasil \\ rbonisilva@gmail.com \\ Mônica Mata Machado de Castro \\ Professora aposentada da Universidade Federal de Minas Gerais, Brasil \\ monicammc@terra.com.br
}

Resumo $O$ trabalho analisa a participação política no continente americano, utilizando como fonte de dados as rodadas de 2004, 2006-2007, 2008, 2010 e 2012 da pesquisa Barômetro das Américas. O conceito de participação política é discutido, de forma a propor sua classificação levando em conta várias dimensões e descrever sua distribuição e intensidade. Também são comparadas a frequência e a intensidade do ativismo político dos americanos e caribenhos com as dos cidadãos de outros continentes. Como principais resultados, o artigo destaca a existência de cinco modalidades de participação, verifica que o voto e o ativismo comunitário são as atividades mais frequentes, identifica a nacionalidade dos cidadãos mais e menos participativos e mostra que o nível de ativismo político dos americanos e caribenhos está próximo ao dos cidadãos de outros continentes, como os europeus e os africanos.

Palavras-chave: participação política, América Latina, Barômetro das Américas.

\section{Introdução}

Objetiva-se analisar a participação política nas Américas e no Caribe, tomando como fonte de dados as

1 Este artigo é uma versão parcial e revisada da tese de Robert Bonifácio (2014), defendida em março de 2014 no Programa de Pós-Graduação em Ciência Política da Universidade Federal de Minas Gerais, intitulada "Corrupção e Participação Política nas Américas e no caribe: 2004 a 2012". 
rodadas de 2004, 2006-2007, 2008, 2010 e 2012 da pesquisa Barômetro das Américas². O tema, apesar de muito estudado na ciência política, continua relevante e atual, considerando-se não só as consequências da participação política para o funcionamento do regime democrático nas sociedades contemporâneas, mas também por ser esse um fenômeno múltiplo em manifestação e significado.

Discute-se o conceito de participação política, buscando identificar a complexidade do fenômeno; a seguir propõe-se uma classificação dessa ação, levando em conta suas dimensões e, finalmente, descreve-se a sua distribuição, no recorte geográfico e temporal considerado.

$\mathrm{O}$ trabalho tem duas partes principais. $\mathrm{Na}$ primeira, comparam-se alguns dos principais estudos sobre participação política, destacando suas semelhanças e diferenças no que concerne à conceituação e às dimensões levadas em conta. Como resultado, sugere-se uma definição de participação política e selecionam-se seus possíveis indicadores empíricos. A segunda parte é de análise empírica dos dados sobre os tipos de participação dos cidadãos de países americanos e caribenhos, de 2004 a 2012. Ressalta-se a natureza multidimensional do fenômeno, apontam-se as atividades participativas mais frequentes e a intensidade de ativismo, identificam-se as nacionalidades dos cidadãos mais e menos participativos e comparam-se os resultados com dados similares, relativos a cidadãos de outros continentes e países.

Alguns critérios justificam a escolha do Barômetro das Américas como fonte de dados. Um deles é a riqueza do questionário utilizado: ele contém dezenas de questões sobre participação política. Além disso, a pesquisa cobre um período de cerca de uma década, na qual as entrevistas foram aplicadas bianualmente, sem interrupções.

A análise dos dados é descritiva, visando um mapeamento do engajamento participativo dos entrevistados, no período considerado. A potencial contribuição ao estudo do tema está no fato de que se leva em conta a quase totalidade dos países das Américas e do Caribe, em cinco rodadas sucessivas do Barômetro das Américas, algo inédito na literatura especializada. Assim, espera-se que as reflexões e os resultados aqui apresentados incorporem novos conhecimentos sobre a questão, impulsionando estudos com objetivos similares.

Importante ressaltar que não se utilizam variáveis indicadoras de participação política digital (via internet). Isso porque o fenômeno é recente, sendo ainda incipiente a abordagem pela literatura especializada. Ademais, as pesquisas de opinião exploradas não contemplam esse tipo de participação no período temporal selecionado.

2 Trata-se de um conjunto de pesquisas de opinião aplicadas em diversos países das Américas e do Caribe, realizado pelo Latin American Public Opinion Project (LAPOP), da Vanderbilt University, sob coordenação de Mitchell Seligson. Para mais informações, acesse: <http://www.vanderbilt.edu/ lapop/>.Acesso em: 10 ago. 2017. 


\section{O conceito de participação política}

Esclarecer o significado dos termos utilizados é tarefa essencial em qualquer esforço analítico, em todos os ramos da ciência. Mais ainda na ciência social, área em que há ainda muita controvérsia sobre definições e classificações que sejam úteis e fecundas para distinguir, descrever fenômenos e propor teorias explicativas sobre a realidade que interessa estudar.

Gerring (1999) sugere como ponto de partida para a construção dos conceitos a utilização de seu significado comum, já popularmente estabelecido, como os fornecidos pelos dicionários. É o que faz Fialho (2008) para definir participação política. O autor acessa três dos mais difundidos dicionários brasileiros da língua portuguesa e mostra que todos compartilham a definição de que "participar" é "tomar parte em". Ao consultar dicionários de línguas estrangeiras - como a espanhola, italiana, francesa e inglesa - Fialho (2008) observa que a definição mais usual de "participar" é a mesma também nessas línguas. Afirma, assim, que o significado de participar, entendido como tomar parte em qualquer tipo de atividade, possui uma natureza ativa e expressa a ideia de ação.

Interessa, no entanto, definir participação 'política'. Esse adjetivo indica que a ação incide numa esfera ou campo específico. Fialho (2008) ressalta que o significado recorrente que se atribui à "política" é aquele que a relaciona a questões de Estado e de governo. Porém, uma definição mais rica e fecunda pode extrapolar o terreno das instituições públicas. Reis (1994), por exemplo, considera que o termo política envolve as relações estratégicas - conflituosas ou cooperativas - que visam o poder e, portanto, pode ser analisado em qualquer arena, desde a família, os grupos e associações diversas da sociedade até o governo.

$\mathrm{Na}$ produção teórica da ciência política, há diversos autores que discutiram o significado e os indicadores empíricos da participação política. Pode-se considerar, de modo geral, que há alguma controvérsia sobre aspectos como a natureza do fenômeno se unidimensional, bidimensional ou multidimensional -, sobre o repertório de atividades participativas e sobre a finalidade do ativismo político, dentre outros aspectos.

Um dos autores que iniciaram o debate foi Milbrath (1965), que propõe uma definição unidimensional da participação política, considerando somente as ações que visam influenciar processos eleitorais. Ele também destaca o caráter cumulativo da participação, ressaltando que um cidadão minimamente participativo tende, com o passar do tempo, a engajar-se cada vez mais em outros tipos de atividades. O autor constrói uma classificação hierárquica das atividades políticas e utiliza os nomes dos papeis exercidos por romanos na arena de gladiadores - apáticos, espectadores e gladiadores - para distinguir as atividades num continuum. Assim, por exemplo, classifica como apáticos os que não se envolvem em qualquer atividade, como espectador quem vota e como gladiador o postulante a cargo político.

A natureza unidimensional da participação política, concebida por Milbrath (1965),é analisada por Norris (2007), Ribeiro e Borba (2011) e Borba (2012) como uma evidência 
de que Milbrath considera como alvo único do ativismo político os governos. Assim, ele teria uma visão restrita sobre o fenômeno.

Huntington e Nelson (1976) especificam que o que está em jogo, quando se fala em participação política, são ações, comportamento, e não atitudes (como interesse por política ou sentimento de eficácia política, por exemplo). Consideram como finalidade da participação política a tentativa de influenciar os processos de decisão governamental, mesmo que não logrem sucesso. Nesse ponto, os autores comungam a mesma concepção de Milbrath (1965), destacando que as atividades participativas compartilham de um mesmo objetivo, o governo.

Contudo, para esses autores, o leque de indicadores de participação política é mais amplo, pois a manifestação do fenômeno é relativamente mais heterogênea do que a pensada por Milbrath (1965). Para Huntington e Nelson (1976), a participação política comporta atuação individual e coletiva, movimentos organizados e espontâneos, periodicidade contínua e esporádica e desenvolvimento pacífico e violento. Ademais, ela não ficaria restrita à arena eleitoral, sendo possível classificá-la em pelo menos cinco tipos: atividade eleitoral, lobby, atividade organizacional, contato com políticos e atos políticos violentos.

Segundo Borba (2012), uma forma de expressão política usual nos dias atuais, os protestos, só passa a ser reconhecida como atividade participativa - em estudo empírico sistemático - a partir do trabalho de Barnes et al. (1979). Para Borba (2012), a menor importância dada pela literatura do campo da participação política aos protestos reside no fato dessa atividade ter sido mais usual, pelo menos até meados da década de 1960, em países menos desenvolvidos ou subdesenvolvidos. Isso teria atribuído aos protestos uma conotação antidemocrática, já que esses países se caracterizavam pela instabilidade política, expressa na alternância de governos com feições ora democráticas, ora autocráticas. Sendo assim, os movimentos feministas e estudantis e os de contestação à Guerra do Vietnã, por exemplo, contribuíram para mudar o status das atividades de protesto, consideradas, desde então, atividades participativas possíveis também em regimes políticos democráticos.

O trabalho de Barnes et al. (1979) incorpora novos vocábulos aos estudos da área, ao separar as atividades participativas entre "convencionais" e "não convencionais". Assim, a participação política seria bidimensional: de um lado, as atividades usuais, circunscritas à arena eleitoral, de outro, as contestatórias, expressas por protestos, ocupações de espaços públicos e privados e por assinatura de petições. Em cada um dos tipos de participação, haveria um continuum, análogo ao proposto por Milbrath (1965): o engajamento se dá de modo cumulativo e as atividades participativas estão dispostas hierarquicamente, sendo umas consideradas mais intensas que outras. Barnes et al. (1979) formulam uma "tipologia de intensidade da ação política", na qual classificam os indivíduos como inativos, conformistas, reformistas, ativistas e manifestantes (protesters).

Alguns autores, no entanto, criticam as contribuições de Barnes et al. (1979). Brady (1999) ressalta o caráter homogeneizante que tais autores atribuem às atividades inscritas em cada um dos dois tipos de participação considerados. Já Teorell, Torcal e Montero (2007) consideram obscuros os critérios de hierarquização das atividades em cada um dos 
dois tipos de participação. Pode-se adicionar a essas críticas o fato dos termos utilizados para as modalidades de participação política - "convencional" e "não convencional" serem historicamente datados. O que era pouco convencional à época, como os protestos, é atualmente uma importante via de ativismo político em diversos países democráticos.

Booth e Seligson (1976) fazem críticas às concepções predominantes de participação política. Entendem que, de uma forma geral, elas atribuem apenas às populações urbanas o comportamento participativo na política e restringem as atividades participativas à arena eleitoral. As consequências da disseminação dessas ideias seriam diversas, estando entre elas: (1) a formação de importantes lacunas nos estudos sobre formas alternativas de mobilização política, (2) a ocultação do papel de grupos marginais ou de minorias na dinâmica participativa, e (3) o excessivo foco na política desenvolvida nos Estados Unidos da América.

Os autores baseiam suas análises em dados de pesquisas de opinião realizadas nas décadas de 1970, em países latino-americanos. Dentre as observações mais relevantes, está a de que o ativismo em organizações locais e aquele voltado para a resolução de problemas comunitários ocupam um papel central no jogo político. O engajamento nessas modalidades de participação possibilitaria aos cidadãos a conquista de melhorias nas suas comunidades, em benefício do coletivo - embora ele possa, também, favorecer interesses particulares, uma vez que estreita os laços dos cidadãos mais marginalizados com a elite política, uma relação que pode servir como trampolim para uma carreira política e para o incremento da riqueza pessoal, por exemplo.

Desse modo,Booth e Seligson (1976) também compartilham a ideia de que a finalidade das atividades participativas é influenciar, direta ou indiretamente, a esfera governamental, assim como defendem Milbrath (1965) e Huntington e Nelson (1976). Contudo, aqueles distinguem-se destes ao acrescentarem, entre os indicadores de participação política, as atividades voltadas à esfera comunitária.

Escrevendo em meados da década de 1990,Verba, Schlozman e Brady (1995) definem participação política como uma atividade que visa influenciar a ação governamental, tanto diretamente - influindo na formulação e na realização de políticas públicas -, como indiretamente - atuando na seleção das pessoas que formulam essas políticas. Também elencam uma série de atividades participativas que extrapolam a arena eleitoral - afastandose de Milbrath (1965) -, mas dedicam-se mais fortemente a analisar os efeitos dos grupos de interesse (organizações não governamentais, sindicatos, grupos de pressão, movimentos políticos etc.) nas decisões governamentais. A principal tese sustentada por esses autores é que a natureza da participação é desigual, com o engajamento nas atividades sendo mais comum entre as pessoas com mais recursos, ou seja, aquelas que possuem condições socioeconômicas mais altas. Além disso, listam mais de trinta indicadores de participação política.

Na visão de Ribeiro e Borba (2011), esse estudo destaca o conteúdo multidimensional da participação e promove uma articulação entre dimensões que a literatura tradicionalmente trata de forma distinta: a participação de cunho político e a participação de cunho social. Por outro lado, essa ampliação do escopo do conceito e dos indicadores de participação política deu margem a críticas, como as de Van Deth (2001), para quem a proposta tem 
problema, por não traçar a linha demarcatória de um conceito mínimo de participação política. O risco, segundo Van Deth (2001), é a ampliação rumo a uma "teoria do tudo".

O trabalho deTeorell,Torcal e Montero (2007) critica a definição de participação política de Verba e Nie (1972), vista como estreita por considerar como atividades participativas apenas as voltadas a influenciar a seleção de políticos e as decisões governamentais. Teorell, Torcal e Montero (2007) afirmam que, em países onde predomina a lógica da economia de mercado, a alocação de valores na sociedade não é papel exclusivo do Estado e dos atores do setor público. Nessas circunstâncias, grandes empresas (como McDonald's, ZARA, empresas petrolíferas, entre outras) e organizações transnacionais (como Organização das Nações Unidas, Fundo Monetário Internacional, Fórum Econômico Mundial) são também alvos dos cidadãos, que visam resultados políticos a partir do ativismo.

A partir dessa concepção, Teorell, Torcal e Montero (2007) propõem a ampliação dos estudos da área, considerando variáveis como o boicote e a compra direcionada de produtos por motivações políticas entre os indicadores de participação política. Distinguem quatro tipos de participação: "contato", "atividades partidárias", "atividades de protesto" e "participação do consumidor" (consumer participation). O último tipo agrega às duas variáveis mencionadas acima, ações relativas a assinar petição e doar dinheiro a partido político.

Pizzorno (1975) é, de longe, o autor aqui abordado que possui a noção mais ampliada a respeito da participação política, definindo-a como uma ação que as pessoas cumprem em solidariedade umas com as outras, no âmbito do Estado ou de uma classe, com vistas a conservar ou modificar a estrutura - e, portanto, os valores - do sistema de interesses dominantes.

Na concepção de Pizzorno (1975), as ações participativas objetivam, como produto final, influenciar o aparato estatal. Porém, ao contrário dos demais autores citados anteriormente, ele vislumbra a possibilidade de modificação radical via participação política, indo muito além da influência nas decisões governamentais e da seleção de líderes políticos. Segundo Pizzorno (1975), a participação política em contextos de sufrágio universal leva à configuração de dois cenários. Um é congruente com as regras do jogo da sociedade capitalista, que são por natureza desiguais, procurando extrair vantagens das oportunidades que surgem da dinâmica desse sistema. $\mathrm{O}$ outro cenário consiste em atuar fora dessa estrutura de desigualdades, procurando quebrá-la através da luta de classes. O problema para a efetivação desse último cenário é que o sistema de desigualdade funda-se em valores que lhe são congruentes, atingindo um caráter universal em certos contextos. Para que a luta de classes consiga derrubar isso, ela também deve se tornar um valor universal.

Em relação aos tipos de participação política, Pizzorno (1975) ressalta ser necessário distingui-los levando em conta suas diferentes origens e características: a atividade política profissional, a participação como meio da expressão de posições na sociedade civil e a participação como expressão de interesses associativos, mais ou menos isolados das estruturas dominantes. Assim, sua concepção incorpora um perfil participacionista até então excluído pelos demais autores tratados, exceto Milbrath (1965): o "político 
profissional". Além desse, considera como modalidade de ação política a participação civil na política, os movimentos sociais e a subcultura ${ }^{3}$.

Para Borba (2012), Pizzorno (1975) tem o mérito de antecipar em mais de uma década o debate sobre o que posteriormente foi chamada de modalidade "não convencional" de participação política (Barnes et al., 1979) ${ }^{4}$. Ao inserir a questão da identidade como elemento explicativo do envolvimento político, Pizzorno (1975) também influenciou o trabalho de Verba, Schlozman e Brady (1995), que, como sugerido acima, propuseram ser a participação política uma ação dependente dos recursos individuais, em especial, tempo, dinheiro e habilidades. Contudo, Pasquino (2010) lembra que falta clareza a Pizzorno em muitos pontos de sua proposta analítica e que os conceitos criados por ele carecem de operacionalização empírica.

\section{Participação política: uma proposta de definição teórica e de operacionalização}

\subsection{Conceituação de participação política}

A análise acima sugere algumas conclusões preliminares. Em primeiro lugar, não há consenso sobre o significado de participação política.Talvez o único ponto de acordo entre parte dos especialistas seja a proposta de que o fenômeno se expressa por atividades e não por atitudes, ou seja, ele está relacionado a comportamento e não a aspectos subjetivos.

Em segundo lugar, com relação à finalidade da participação política, observa-se mais de uma interpretação. A mais comum é a de que as atividades participativas visam a influenciar decisões governamentais, seja no governo nacional, regional ou local. Entretanto, se o termo política refere-se às ações estratégicas visando à conquista do poder (Reis, 1994), participação pode ser analisada em outras arenas, além da governamental. Pizzorno (1975) vai além ao lembrar que a participação política pode gerar uma transformação estrutural do Estado, sendo a força motriz de reformas profundas e mesmo de revolução política.

Em terceiro lugar, pode-se identificar a incorporação de arenas de atuação e de modalidades diversas ao conceito de participação política à medida que avançam os anos. Em meados da década de 1960, Milbrath (1965) elencava pouco mais de uma dezena de atividades participativas, todas pertencentes à arena eleitoral. Trinta anos depois, Verba, Schlozman e

3 Subcultura é um termo utilizado quase que exclusivamente por Pizzorno (1975) em estudos sobre participação política. É um tipo de participação geralmente exercido por grupos relativamente homogêneos e compostos por tipos sociais marginalizados. Diferencia-se da participação civil e dos movimentos sociais por estar excluído dos canais usuais de comunicação e do acesso institucional. Tendem a não ter comunicação com outros grupos, para evitar a sensação de inferioridade. É uma situação instável, caindo ora na apatia, ora na participação civil.

4 Ressalte-se que a primeira edição da obra de Pizzorno é de 1966. 
Brady $(1995)^{5}$ propõem mais de trinta e dois indicadores, de nove tipos diferentes de participação. Esse movimento expressa a importância que passaram a ter as ações contestatórias, que ajudaram a romper a noção de que participação só se atém à arena eleitoral.

Esse debate contribui para a formulação da definição de participação política considerada neste artigo. Primeiramente, utiliza-se o ponto consensual na literatura: participação remete a comportamento, a ação. Em segundo lugar, entende-se que a participação política pode se desenvolver em diversos ambientes e em vários campos, seja o econômico, o cultural, o político etc. Em terceiro lutar, a definição leva em conta as finalidades das atividades ou os resultados visados, e não as motivações da ação.Assim, considera-se que participação política refere-se a atividades exercidas por indivíduos e grupos, em diversas arenas, com o objetivo de influenciar as dinâmicas de poder. Ressalta-se que a definição proposta nada diz sobre a eficácia ou não da atividade, ou sobre a extensão maior ou menor das transformações promovidas na sociedade e nos governos por meio da participação política.

No Quadro 1, listam-se os possíveis indicadores empíricos de participação política, com base na definição proposta.

Quadro 1. Possíveis indicadores de participação política.

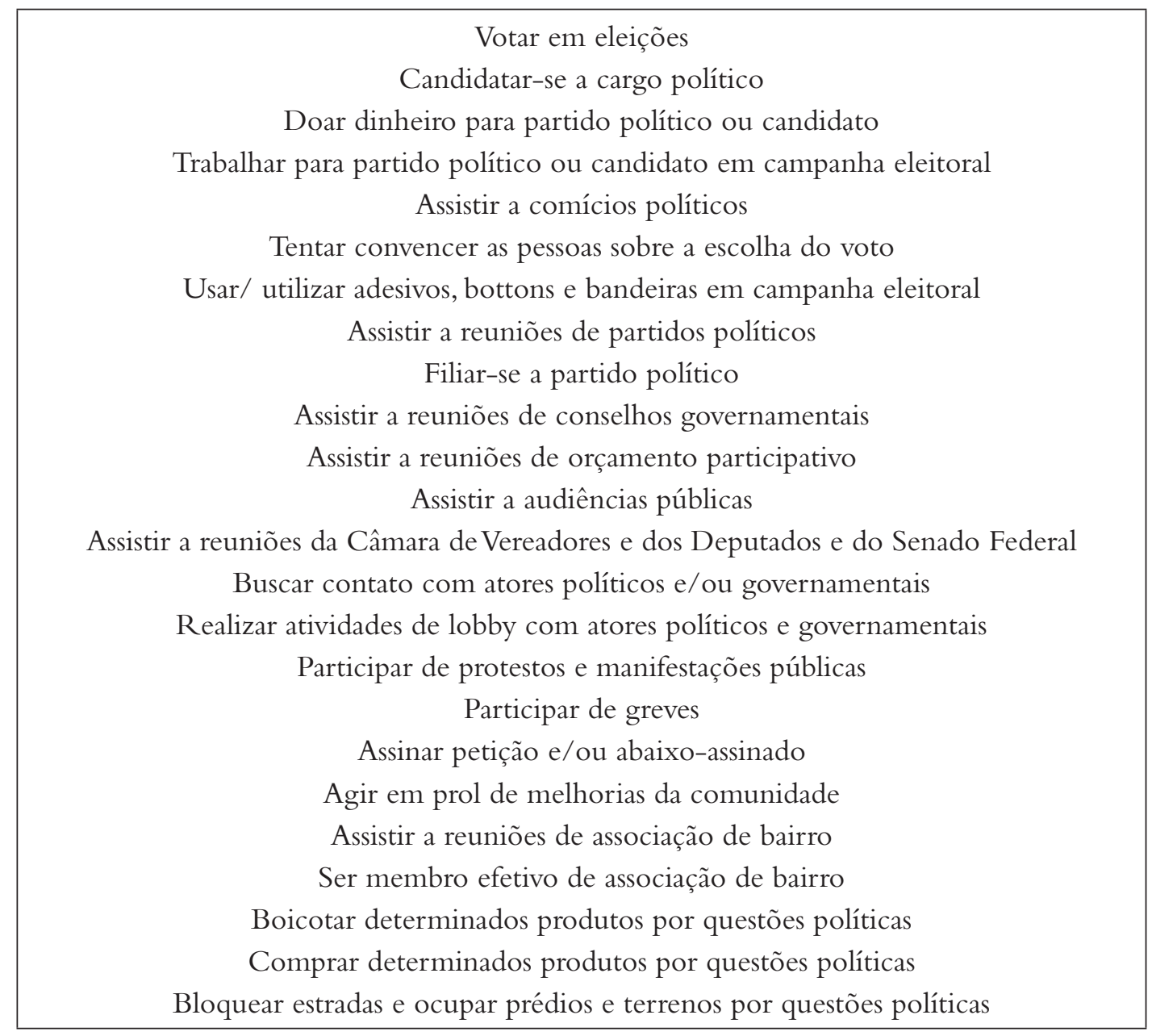

Fonte: elaboração própria (2014).

5 Esse estudo incorpora proposições feitas em estudos anteriores por Verba e seus parceiros, a saber, Verba e Nie (1972) e Verba, Nie e Kim (1987). 
Duas observações são importantes. A primeira refere-se ao alcance da dinâmica participativa, o qual não se incorpora à concepção de que os resultados dessa dinâmica podem contribuir para uma mudança estrutural do Estado (Pizzorno, 1975). Isso porque a ocorrência de movimentos revolucionários mostra-se pouco frequente ao longo da história e o interesse deste trabalho recai sobre as atividades mais usuais. Outra observação é que a filiação a grupos e a associações de tipos diversos, para além dos partidos políticos e das associações comunitárias, não foi incluída na lista proposta acima. Isso porque algumas dessas associações, como as de igrejas, de mulheres ou os grêmios recreativos, por exemplo, podem ou não ter relação com questões políticas. Por não possuírem um caráter político inequívoco, tais filiações foram excluídas da lista de indicadores.

\subsection{As dimensões da participação política}

Com base na lista de indicadores contida no Quadro 1 e na disponibilidade de itens medidos na pesquisa Barômetro das Américas, foram selecionadas treze variáveis como indicadoras de participação política. São elas: ${ }^{6}$
a. Votar na eleição presidencial;
b. Trabalhar em campanha eleitoral;
c. Contatar deputados (estaduais e federais);
d. Contatar atores políticos governamentais (ministérios e secretarias);
e. Contatar atores políticos locais (prefeitos e autoridades militares)
f. Contatar vereadores e atores governamentais locais;
g. Agir para solução de problemas na comunidade em que se vive;
h. Assistir a reuniões de associação de bairro;
i. Assistir a reuniões de partido político;
j. Assistir audiência pública na câmara dos vereadores ou na prefeitura;
k. Tentar convencer outros sobre a escolha do voto;
1. Participar de manifestações ou protestos públicos;
m. Assinar petições.

Embora haja critérios de ordem teórica para sustentar que todas essas variáveis são indicadoras de participação política, é preciso investigar se elas fazem parte de uma mesma dimensão ou se podem ser discriminadas em diferentes tipos, tendo um caráter

6 Informações detalhadas sobre essas variáveis podem ser encontradas em: $<$ http://www.vanderbilt. edu/lapop/>. O código de cada variável é, respectivamente: vb2, pp2, cp2, cp4, cp4a, np2, cp5, cp8, cp13, np1, pp1, prot1 (rodadas de 2004, 2006-7 e 2008)/ prot3 (rodadas de 2010 e 2012) e prot6. As categorias de cada variável consideradas como indicadoras de participação são: vb2 (sim), pp2 (sim), cp2 (sim), cp4 (sim), cp4a (sim), cp5 (rodadas 2004 e 2006/07: sim/ rodadas 2008, 2010 e 2012: uma vez por semana, uma ou duas vezes por mês e uma ou duas vezes por ano), cp8 (uma vez por semana, uma ou duas vezes por mês e uma ou duas vezes por ano), cp13 (uma vez por semana, uma ou duas vezes por mês e uma ou duas vezes por ano), np1 (sim), np2 (sim), pp1 (frequentemente, de vez em quando e muito raramente), prot1 (algumas vezes e quase nunca), prot3 (sim) e prot6 (sim). 
multidimensional. A maneira mais adequada para isso é a utilização do teste de análise fatorial exploratória.

Antes de processar e analisar os dados do Barômetro das Américas, com o objetivo de identificar as possíveis dimensões da participação política, é importante trazer os resultados de outras pesquisas sobre essa questão. O estudo deVerba, Nie e Kim (1987) foi um dos primeiros a tratá-la, numa abordagem comparada. Analisando dados de sete países - Áustria, Índia, Holanda, Nigéria, EUA, Iugoslávia e Japão -, os autores encontram, em todos eles, a mesma tipificação de participação política: a) "comparecimento eleitoral" (ter votado na eleição anterior à realização da pesquisa); b) "ativismo de campanha" (envolvimento em diversas atividades durante a campanha eleitoral, visando favorecer um candidato ou um partido específico na disputa); c) "ativismo comunitário" (ações voltadas a atores e problemas políticos locais); e d) "contatos personalizados" (contatar atores políticos e governamentais). Os autores não tratam de atividades de protesto, considerando-as um tipo específico de participação a ser estudado separadamente.

Essa lacuna não existe nos trabalhos de Norris (2002) e Booth e Seligson (2009). Nesses, o número de indicadores de participação política é ampliado e são construídos tipos a partir de pesquisas de opinião que incluem entrevistados de um maior número de países.

Norris (2002) utiliza um conjunto de pesquisas aplicado em mais de cinquenta países em meados da década de 1990 e encontra três dimensões de participação política: a) "ativismo cívico" (associação a diversas organizações, como as religiosas, esportivas e partidos políticos); b) “ativismo de protesto" (engajamento em atividades não convencionais ou contestatórias, como protestos, assinatura de petições, ocupações de prédios e fábricas etc.) e c) "comparecimento eleitoral". O resultado considerado mais relevante pela autora é a existência de uma dimensão própria para as variáveis sobre participação não convencional ou contestatória, indicando um sentido específico na manifestação política por meio desses canais.Variáveis sobre contato com atores políticos e governamentais não são incluídas nessa análise.

Em Booth e Seligson (2009), são utilizados os dados do Barômetro das Américas de 2004. Dentre as variáveis indicadoras de participação política, os autores classificam quatro modalidades específicas: a) "registro como eleitor e voto"; b) "ativismo de campanha e partidário"; c) "contato com políticos e autoridades" e d) "ativismo comunitário". De modo suplementar ao teste de análise fatorial realizado, os autores acrescentam, considerando somente a dimensão teórica - pois não submetem as variáveis a qualquer teste de associação -, mais dois tipos de participação política: e) "protestos” e f) "ativismo civil" (assistir a reuniões escolares, de grupos religiosos, de grupos para melhorias da comunidade e de grupos comerciais e profissionais).

O número de variáveis incluídas nessas análises varia nos três estudos, mas, de forma geral, pode-se afirmar que os mais recorrentes são os indicadores de a) "ativismo de campanha", b) "contato com atores políticos e governamentais", c) "protestos", d) “ativismo comunitário" e e) "comparecimento eleitoral”. 
Como as treze variáveis selecionadas como indicadoras de participação política para este artigo abarcam quase que a totalidade dos itens incluídos nos cinco tipos acima, esperase encontrar resultados semelhantes por meio dos testes de análise fatorial exploratória ${ }^{7}$.

A Tabela 1 traz o resultado dessa análise. Utilizam-se, em conjunto, os dados completos de todas as rodadas do Barômetro da Américas. É possível discriminar os tipos de participação política por meio das variáveis incluídas nos diferentes fatores. Num primeiro momento, distinguem-se três tipos: a) contato com atores políticos e governamentais, b) ativismo comunitário e c) ativismo eleitoral.

O primeiro tipo expressa o contato direto entre representante(s) e representado(s), provavelmente com o objetivo de exercer pressão, manifestar opinião ou encaminhar algum pedido. Com base na redação das perguntas no questionário, não se pode afirmar se o contato ocorre de forma individual ou coletiva e tampouco se conhece a natureza das questões tratadas.

O segundo, o ativismo comunitário, inclui atuação em questões políticas de abrangência local. Busca-se participar nas ações e na tomada de decisão sobre políticas voltadas para solução dos problemas da comunidade em que se vive.

Já o ativismo eleitoral inclui atividades que se caracterizam pela tentativa de influenciar resultados eleitorais. Ademais, a atuação está circunscrita a instituições e eventos oficiais, como os partidos políticos e as eleições.

Uma análise mais detida dos dados, porém, revela a existência de mais dois tipos de participação política: comparecimento eleitoral e ativismo de protesto. $\mathrm{O}$ maior coeficiente da variável indicadora de voto entre os fatores, em cada rodada, apresenta patamar de baixo a moderado, sem ultrapassar o valor de 0,431. Esse valor destoa (para baixo) das demais variáveis que constituem o fator em que a variável indicadora de voto se encontra, em cada rodada. Essa constatação, adicionada aos resultados encontrados por Verba, Nie e Kim (1987), Norris (2002) e Booth e Seligson (2009), reforça a decisão de que o voto deve ser tratado como modalidade específica de participação política.

A variável de participação em protestos também parece fora de lugar entre os fatores nas quatro primeiras rodadas. $\mathrm{O}$ valor de seu coeficiente estatístico também apresenta de

7 Esse teste é mais indicado para variáveis contínuas, o que não é o caso das variáveis utilizadas neste artigo, binárias e categóricas. Como solução, aplicou-se uma matriz policórica de correlação, tratando os parâmetros pela técnica de estimação de mínimos quadrados ponderados aos dados, técnica recomendada por Jöreskog e Sörbom (1979). Para a seleção da quantidade de fatores a serem usados na análise, usou-se como critério os valores eigenvalue que são iguais ou maiores que um. Nas quatro primeiras rodadas, três fatores cobriram esse critério e na última, quatro fatores. Uma das medidas de confiabilidade dos dados é a consistência interna, que remete à ideia de que os itens ou indicadores individuais da escala devem medir o mesmo constructo e, assim, ser altamente interrelacionados. O alpha de Cronbach é comumente utilizado; sua variação é de 0 a 1 , sendo o patamar mínimo usualmente aceitável de 0,60 em pesquisa exploratória (Hair et al., 2005). Nesta pesquisa utilizou-se alpha de Cronbach padronizado, sendo seus coeficientes, para as rodadas de 2004, 2006/7, 2008, 2010 e 2012, respectivamente: 0,689, 0,674, 0,678,0,689; e 0,699. Por fim, cabe destacar que se aplicou ao conjunto de dados de cada rodada a variável de peso intitulada weight 1500 , visando uniformizar em 1500 o número de casos em cada país. 
baixa a moderada intensidade, sendo que um valor expressivo (acima de 0,7 ) é observado apenas na última rodada, de 2012. Nesse caso, juntamente com a assinatura de petição e abaixo-assinado, variável incluída somente nessa rodada, há a clara conformação de um fator específico, intitulado ativismo de protesto. 
Tabela 1. Análise fatorial exploratória com indicadores de participação política

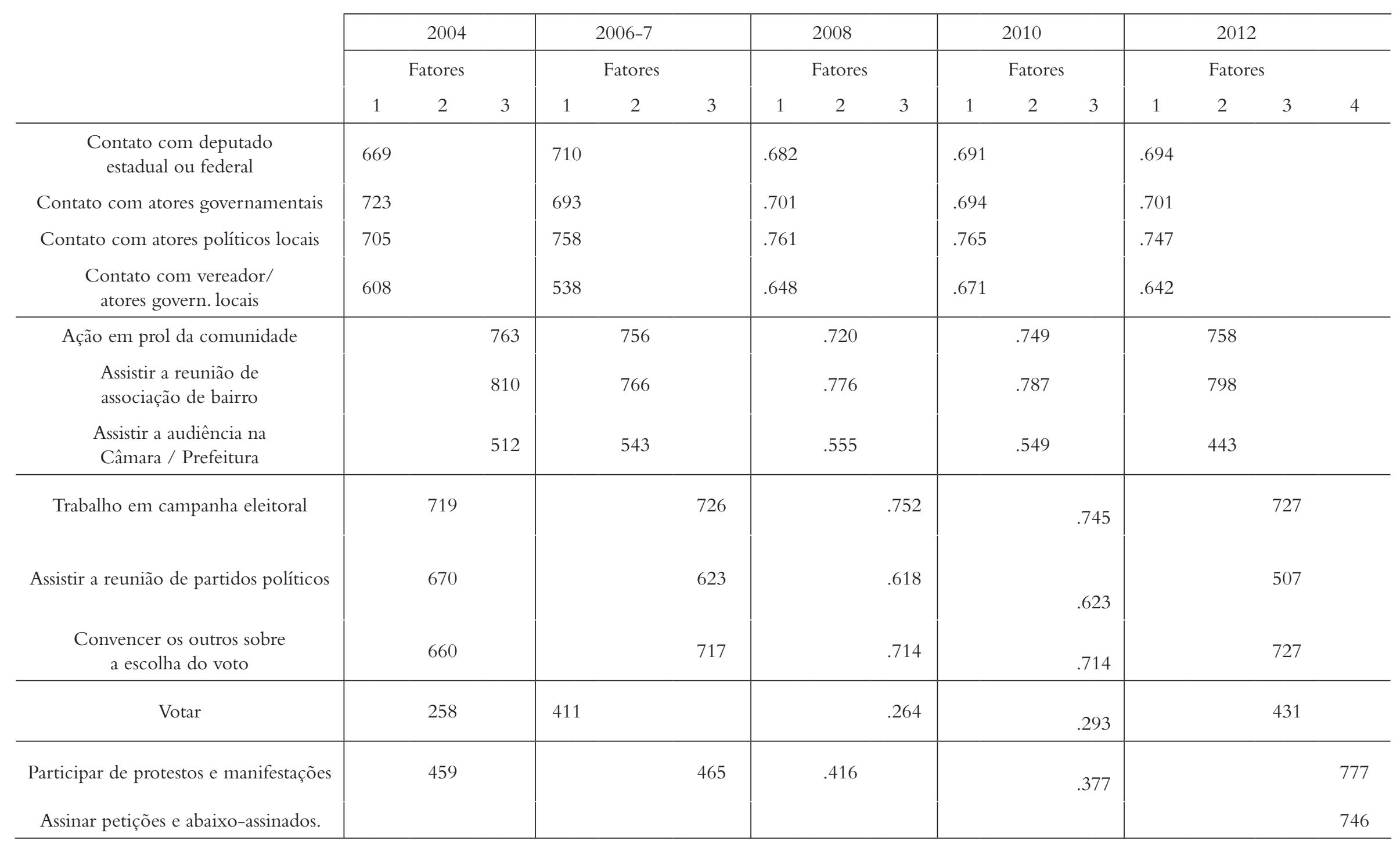

Fonte: elaboração própria (2014), a partir dos dados do Barômetro das Américas. 
O Quadro 2 apresenta o nome da cada tipo de participação política encontrado por meio da análise fatorial, assim como os seus indicadores.

Quadro 2. Tipos ou modalidades de participação política e seus indicadores

(1) Contato com atores políticos e governamentais: contato com deputado estadual e federal, com ator político local, com ator governamental e com vereador e atores governamentais locais.

(2) Ativismo comunitário: assistir a reuniões de associação de bairro, agir em prol de melhorias na comunidade e assistir a audiência em Câmara de Vereadores e Prefeitura.

(3) Ativismo eleitoral: trabalho em campanha eleitoral, assistir a reuniões de partido político, tentar convencer os outros sobre a escolha do voto.

(4) Comparecimento eleitoral: ter votado na eleição anterior.

(5) Ativismo de protesto: participação em manifestações e protestos e assinatura de abaixo-assinado e petição.

Fonte: elaboração própria (2014), a partir dos dados do Barômetro das Américas.

Os resultados apresentados acima fortalecem os achados de outros estudos - como os de Verba, Nie e Kim (1987), Norris (2002), Booth e Seligson (2009) e Teorell, Torcal e Montero (2007) - que mostram a natureza multidimensional da participação política. Diante de tantas evidências sobre os diferentes tipos de participação política, parece inadequado concebê-la como um fenômeno uno, restrito ao ambiente governamental e eleitoral.Ademais, as diferentes características de cada uma das modalidades de participação - especialmente no que tange ao ambiente de sua manifestação, ao objetivo visado e ao tempo envolvido em sua realização - sugerem considerar a hipótese de que cada uma das modalidades atrai perfis sociais distintos de indivíduos para a ação política.

\subsection{Frequência e intensidade de ativismo político}

Não há na literatura especializada um estudo que busque mapear de forma ampla - em relação a número de casos e ao período temporal - a participação política no contexto das Américas e do Caribe. Somente alguns estudos trazem indicações a esse respeito, focando um tipo de participação política ao longo dos anos ou descrevendo a frequência de diversas atividades para um único ano (Montalvo, 2008; Corral, 2008, 2009a, 2009b; Rennó et al., 2011).

A Tabela 2 apresenta a frequência de participação nas diversas atividades consideradas neste artigo, para as diferentes rodadas do Barômetro das Américas. Os indicadores estão colocados em ordem do mais ao menos intenso, levando-se em conta a média das frequências ${ }^{8}$.

8 Apresentamos o percentual de frequência de cada atividade participativa para o conjunto de dados das pesquisas de opinião, por rodada. A coluna "média" mostra a frequência média, o resultado da soma de todos os percentuais, dividido pelo número total de rodadas. O ranking é a posição relativa de cada uma das atividades levando em conta o percentual de frequência média. 
Tabela 2. Frequência e ranking das atividades participativas (\%)

\begin{tabular}{|c|c|c|c|c|c|c|c|}
\hline Atividade & 2004 & $2006 / 7$ & 2008 & 2010 & 2012 & Média & Ranking \\
\hline Votar & 74,3 & 75,5 & 74,6 & 74,1 & 76,0 & 75,5 & $1^{o}$ \\
\hline $\begin{array}{l}\text { Ação em prol de melhorias } \\
\text { na comunidade }\end{array}$ & 34,1 & 36,1 & 35,7 & 35,7 & 34,6 & 35,3 & $2^{\circ}$ \\
\hline $\begin{array}{l}\text { Convencer os outros sobre } \\
\text { a escolha do voto }\end{array}$ & 26,3 & 33,8 & 36,3 & 32,5 & 32,8 & 34,6 & $3^{\circ}$ \\
\hline $\begin{array}{l}\text { Assistir a reunião de } \\
\text { associação de bairro }\end{array}$ & 32,7 & 28,9 & 29,1 & 26,6 & 24,1 & 26,9 & $4^{\circ}$ \\
\hline $\begin{array}{l}\text { Assistir a reunião de } \\
\text { partido político }\end{array}$ & 17,0 & 14,4 & 15,8 & 17,7 & 15,4 & 17,0 & $5^{\circ}$ \\
\hline $\begin{array}{l}\text { Contato com atores políticos locais } \\
\text { (prefeito/ autoridades militares) }\end{array}$ & 21,7 & 14,5 & 13,4 & 14,7 & 14,0 & 14,9 & $6^{\circ}$ \\
\hline $\begin{array}{l}\text { Contato com vereador/ atores } \\
\text { governamentais locais }\end{array}$ & 15,3 & 14,9 & 12,5 & 13,7 & 12,6 & 13,7 & $7^{\circ}$ \\
\hline Participação em protestos & 17,3 & 20,0 & 22,3 & 7,9 & 7,6 & 12,5 & $8^{\circ}$ \\
\hline $\begin{array}{l}\text { Assistir a audiência pública } \\
\text { na Câmara Municipal } \\
\text { e/ ou Prefeitura }\end{array}$ & 13,2 & 12,1 & 10,7 & 11,8 & 11,2 & 11,8 & $9^{\circ}$ \\
\hline Assinar petição ou abaixo-assinado & - & - & - & - & 11,5 & 11,5 & $10^{\circ}$ \\
\hline Trabalhar em campanha eleitoral & 12,0 & 11,2 & 10,9 & 10,9 & 8,8 & 10,5 & $11^{\circ}$ \\
\hline $\begin{array}{c}\text { Contato com atores } \\
\text { governamentais } \\
\text { (ministério/ secretaria) }\end{array}$ & 10,5 & 8,5 & 8,8 & 10,1 & 9,7 & 10,0 & $12^{\circ}$ \\
\hline $\begin{array}{l}\text { Contato com deputado } \\
\text { estadual ou federal }\end{array}$ & 9,3 & 6,9 & 6,0 & 7,9 & 7,3 & 8,0 & $13^{\circ}$ \\
\hline
\end{tabular}

Fonte: elaboração própria (2014), a partir dos dados do Barômetro das Américas.

Nota-se que votar é a atividade mais usual entre os americanos e caribenhos: 75,5\% dos cidadãos, em média, afirmaram ter comparecido nas eleições presidenciais anteriores, nas cinco rodadas de pesquisas analisadas. Tal resultado é o esperado, uma vez que essa atividade requer menos esforço para ser realizada, além de mobilizar mais a população. Provavelmente, o fato de o voto ser obrigatório ${ }^{9}$ em boa parte dos países também explica o percentual médio bem maior do que o encontrado para qualquer outra atividade realizada por americanos e caribenhos.

Destaca-se também o papel das atividades participativas ligadas a problemas locais. A ação em prol de melhorias na comunidade é a segunda mais praticada. Dentre as atividades de contato, a que se direciona a atores políticos locais é a mais frequente. Ademais, assistir

9 Em doze países das Américas e do Caribe, o voto é compulsório. São eles: Argentina, Bolívia, Brasil, Chile, Costa Rica, República Dominicana, Equador, México, Panamá, Paraguai, Peru e Uruguai. Disponível em: <http://www.idea.int/vt/compulsory_voting.cfm>. Acesso em: 10 ago. 2017. 
a reuniões de associação de bairro, a quarta atividade mais comum, supera em cerca de $10 \%$ a porcentagem de assistir a reuniões partidárias.

Os resultados sobre a frequência das atividades participativas de cunho comunitário, aliados à constatação de que seus indicadores constituem uma modalidade específica de participação política, reforçam os argumentos de Booth e Seligson (1976), que alertavam para a centralidade do ativismo político de nível local entre os latino-americanos.

As atividades chamadas de não convencionais ou contestatórias, como assinatura de petições e participação em protestos, ocupam posição intermediária, com frequências próximas a $12 \%$. Já o envolvimento com atores políticos e governamentais tradicionais e de abrangência nacional mostra-se o tipo menos comum de participação.

Excetuando-se o voto, a média percentual de envolvimento dos cidadãos nas demais atividades é inferior a 50\%. Isso significa que essas formas de participação política não fazem parte da rotina da maior parte dos americanos e caribenhos. Esse cenário se mostra relativamente estável ao longo dos anos pesquisados, com pequenas alterações nos percentuais.

As maiores variações percentuais no período ocorrem em relação a contato com atores políticos locais, tentativa de convencer outros na escolha do voto, assistir a reunião de associação de bairro e participação em protestos. Na primeira e na segunda dessas variáveis, notamos uma clara diferença entre a primeira rodada e as seguintes, com aumento, na primeira, e queda de percentuais, na segunda. Em ambos os casos, a variação é de aproximadamente $7 \%$ e verifica-se uma estabilidade nos percentuais no período subsequente, ficando em torno de $14 \%$ para contato com atores políticos locais e entre $33 \%$ e $36 \%$ para a tentativa de convencer os outros sobre a escolha do voto.

A tendência na variável assistir a reunião de associação de bairro, por sua vez, é de queda paulatina dos percentuais, embora a trajetória descendente não seja perfeitamente linear.

Por fim, identifica-se uma tendência de aumento paulatino nos percentuais de participação em protestos nas três primeiras rodadas e uma queda abrupta nas duas rodadas subsequentes, com a frequência estabilizando-se em cerca de 8\%. É importante registrar que a flutuação no percentual da variável sobre protestos provavelmente se deve às mudanças realizadas em sua medição. Houve alteração na redação da pergunta aplicada aos entrevistados: nas três primeiras rodadas do Barômetro das Américas, ela se refere à participação em manifestações e protestos durante algum período da vida, ao passo que, a partir de 2010, os entrevistados são questionados sobre o seu engajamento nesse tipo de atividade ao longo dos doze meses anteriores à realização da pesquisa.

Ao agregarem-se os indicadores por tipo de participação política, na Tabela 3, observa-se uma clara hierarquia na distribuição. Em primeiro lugar, o comparecimento eleitoral, seguido de ativismo comunitário e ativismo eleitoral; por fim, o ativismo de protesto e o contato, com percentuais próximos. Importa destacar a posição intermediária que o ativismo eleitoral ocupa, em termos de frequência. Esse resultado indica que a proposta de Milbrath (1965), que arrola as atividades participativas eleitorais como as 
únicas indicadoras de participação política, faz pouco sentido para entender o fenômeno, pelo menos no contexto americano e caribenho mais recente.

Tabela 3. Percentual médio e ranking das modalidades de participação política10

\begin{tabular}{c|c|c}
\hline Modalidades & $\begin{array}{c}\text { Percentual } \\
\text { médio } \\
\text { (em \%) }\end{array}$ & Ranking \\
\hline Comparecimento eleitoral & 75,5 & $1^{\circ}$ \\
Ativismo comunitário & 25,7 & $2^{\circ}$ \\
Ativismo eleitoral & 20,7 & $3^{\circ}$ \\
Ativismo de protesto & 12,0 & $4^{\circ}$ \\
Contato com atores políticos & 11,6 & $5^{\circ}$ \\
e governamentais &
\end{tabular}

Fonte: elaboração própria (2014), a partir dos dados do Barômetro das Américas.

É relevante analisar, também, os percentuais de ativismo comparando os diversos países inseridos na amostra do Barômetro das Américas, com o objetivo de identificar onde há, no período, mais e menos participação política. O critério adotado para isso é a contagem do número de vezes em que determinado país figura entre as três primeiras e as três últimas posições no ranking de frequência de cada atividade, respectivamente ${ }^{11}$. A Tabela 4 contém as informações sobre a nacionalidade dos cidadãos mais e menos participativos por tipo de participação política e a Tabela 5 comporta essas mesmas informações, mas em relação a cada atividade específica.

Considerando os dados de todos os indicadores de participação, identifica-se que o Canadá - que ocupa seis vezes as três primeiras posições de ativismo, considerando todas as atividades participativas - os EUA e o Haiti (ambos cinco vezes nessa posição) e a República Dominicana (quatro vezes nessa posição) são os países dos cidadãos mais participativos, ao passo que em Honduras, no Panamá, na Argentina e no Equador, países que figuram quatro vezes entre as três últimas posições de ativismo, encontram-se os menos participativos.

Do conjunto de dados a respeito, dois pontos devem ser destacados. Em relação ao voto, os mais participativos estão inseridos em contextos onde ele é compulsório, enquanto os cidadãos menos participativos vivem em países onde o sistema eleitoral faculta o direito ao voto. Esses resultados indicam que é importante analisar separadamente países com sistemas eleitorais de voto compulsório e facultativo, especialmente ao investigar os fatores determinantes do comparecimento eleitoral.

10 Para cada modalidade, é feita a média das médias das variáveis constituidoras, chegando-se ao percentual exposto na tabela. Exemplo: "ativismo comunitário"- Ação em prol de melhorias na comunidade $(35,3 \%)+$ Assistir a reunião de associação de bairro $(26,9 \%)$ + Assistir a audiência pública na Câmara Municipal e/ ou Prefeitura $(11,8 \%) / 3=25,7 \%$.

11 Cabe ressaltar que não há correção para ausência de países e variáveis indicadoras ao longo das rodadas. Utilizamos a média simples, calculada a partir dos percentuais das variáveis indicadoras dos países, independente da quantidade de vezes que os países e/ou variáveis indicadoras aparecem na série histórica. 
Também é possível notar, a partir dos dados presentes nas Tabelas 4 e 5, que os países americanos e caribenhos variam muito em suas posições nas diversas atividades participativas. Os surinameses, por exemplo, estão entre os mais participativos na modalidade de ativismo eleitoral, mas, por outro lado, são os menos participativos em atividades de protesto.

Ademais, cidadãos de determinados países mostram-se os mais ativos em tipos de participação marcantemente distintos entre si. Por exemplo, os canadenses são mais ativos tanto em contato com atores políticos e governamentais, uma das formas convencionais de participação política; quanto em ativismo de protesto, a forma mais contestatória de participação. Da mesma forma, haitianos e dominicanos são os mais participativos tanto em ativismo comunitário, quanto em ativismo eleitoral, os quais expressam diferentes modalidades de participação política.

Tabela 4. Nacionalidade dos cidadãos mais e menos participativos, por tipos de participação política ${ }^{12}$

\begin{tabular}{|c|c|c|}
\hline Modalidades & $\begin{array}{l}\text { Países com cidadãos } \\
\text { mais participativos }\end{array}$ & $\begin{array}{l}\text { Países com cidadãos } \\
\text { menos participativos }\end{array}$ \\
\hline \multirow{3}{*}{ Comparecimento eleitoral } & Peru & Honduras \\
\hline & Uruguai & Colômbia \\
\hline & Equador & Jamaica \\
\hline \multirow{3}{*}{ Contato com atores políticos e governamentais } & EUA (3) & Honduras (3) \\
\hline & Canadá (2) & Equador (3) \\
\hline & Trinidade e Tobago (2) & Panamá (2) \\
\hline \multirow{3}{*}{ Ativismo comunitário } & Haiti (3) & Argentina (3) \\
\hline & Rep. Dominicana (2) & Panamá (2) \\
\hline & Suriname (3) & \\
\hline \multirow[t]{2}{*}{ Ativismo eleitoral } & Haiti (2) & Chile (2) \\
\hline & Rep. Dominicana (2) & \\
\hline \multirow[t]{2}{*}{ Ativismo de protesto } & \multirow{2}{*}{ Canadá (2) } & Suriname (2) \\
\hline & & Jamaica (2) \\
\hline
\end{tabular}

Fonte: elaboração própria, 2014, a partir dos dados do Barômetro das Américas.

12 Nas Tabelas 4 e 5, usamos como critério de alocação dos países o número de vezes em que ele figura nas três primeiras e três ultimas posições. 
Tabela 5. Países com cidadãos mais e menos participativos, por indicadores de participação

\begin{tabular}{|c|c|c|}
\hline Atividades & $\begin{array}{l}\text { Países com cidadãos } \\
\text { mais participativos }\end{array}$ & $\begin{array}{l}\text { Países com cidadãos } \\
\text { menos participativos }\end{array}$ \\
\hline Votar & $\begin{array}{c}\text { Peru } \\
\text { Uruguai } \\
\text { Equador }\end{array}$ & $\begin{array}{l}\text { Honduras } \\
\text { Colômbia } \\
\text { Jamaica }\end{array}$ \\
\hline Ação em prol de melhorias na comunidade & $\begin{array}{c}\text { Paraguai } \\
\text { Haiti } \\
\text { Rep. Dominicana }\end{array}$ & $\begin{array}{l}\text { Panamá } \\
\text { Argentina } \\
\text { Nicarágua }\end{array}$ \\
\hline Convencer os outros sobre a escolha do voto & $\begin{array}{c}\text { EUA } \\
\text { Canadá } \\
\text { Suriname }\end{array}$ & $\begin{array}{l}\text { El Salvador } \\
\text { Nicarágua } \\
\text { México }\end{array}$ \\
\hline Assistir a reunião de associação de bairro & $\begin{array}{l}\text { Bolívia } \\
\text { Haiti } \\
\text { Canadá }\end{array}$ & $\begin{array}{l}\text { Brasil } \\
\text { Argentina } \\
\text { Uruguai }\end{array}$ \\
\hline Assistir a reunião de partido político & $\begin{array}{c}\text { Suriname } \\
\text { Rep. Dominicana } \\
\text { Haiti }\end{array}$ & $\begin{array}{l}\text { Equador } \\
\text { Costa Rica } \\
\text { Chile }\end{array}$ \\
\hline $\begin{array}{l}\text { Contatar atores políticos locais } \\
\text { (prefeito/ autoridades militares) }\end{array}$ & $\begin{array}{c}\text { El Salvador } \\
\text { EUA } \\
\text { Canadá }\end{array}$ & $\begin{array}{l}\text { Honduras } \\
\text { Equador } \\
\text { Panamá }\end{array}$ \\
\hline Contatar vereador/ atores governamentais locais & $\begin{array}{l}\text { Uruguai } \\
\text { Peru } \\
\text { Chile }\end{array}$ & $\begin{array}{l}\text { Equador } \\
\text { Honduras } \\
\text { Panamá }\end{array}$ \\
\hline Participação em protestos & $\begin{array}{c}\text { Bolívia } \\
\text { Peru } \\
\text { Canadá }\end{array}$ & $\begin{array}{l}\text { Jamaica } \\
\text { El Salvador } \\
\text { Suriname }\end{array}$ \\
\hline $\begin{array}{c}\text { Assistir a audiência pública na Câmara } \\
\text { Municipal e/ ou Prefeitura }\end{array}$ & $\begin{array}{c}\text { Rep. Dominicana } \\
\text { EUA } \\
\text { Haiti }\end{array}$ & $\begin{array}{l}\text { Chile } \\
\text { Argentina } \\
\text { Panamá }\end{array}$ \\
\hline Assinar petição ou abaixo-assinado & $\begin{array}{c}\text { EUA } \\
\text { Canadá } \\
\text { Brasil }\end{array}$ & $\begin{array}{l}\text { Guiana } \\
\text { Suriname } \\
\text { Jamaica }\end{array}$ \\
\hline Trabalhar em campanha eleitoral & $\begin{array}{c}\text { Rep. Dominicana } \\
\text { Suriname } \\
\text { Haiti }\end{array}$ & $\begin{array}{l}\text { Peru } \\
\text { Canadá } \\
\text { Chile }\end{array}$ \\
\hline $\begin{array}{l}\text { Contatar atores governamentais } \\
\text { (ministério/ secretaria) }\end{array}$ & $\begin{array}{c}\text { EUA } \\
\text { Canadá } \\
\text { Trinidade e Tobago }\end{array}$ & $\begin{array}{l}\text { Paraguai } \\
\text { Haiti } \\
\text { Honduras }\end{array}$ \\
\hline Contatar deputado estadual ou federal & $\begin{array}{c}\text { EUA } \\
\text { Jamaica } \\
\text { Trinidade e Tobago }\end{array}$ & $\begin{array}{l}\text { Argentina } \\
\text { Peru } \\
\text { Equador }\end{array}$ \\
\hline Geral & $\begin{array}{c}\text { Canadá (6) } \\
\text { EUA e Haiti (5) } \\
\text { Rep. Dominicana (4) }\end{array}$ & $\begin{array}{l}\text { Honduras } \\
\text { Panamá } \\
\text { Argentina } \\
\text { Equador (4) }\end{array}$ \\
\hline
\end{tabular}

Fonte: elaboração própria (2014), a partir dos dados do Barômetro das Américas. 
Para analisar o repertório de participação política, é possível, ainda, examinar a Tabela 6, que mostra as percentagens de entrevistados que afirmaram ter participado de nenhuma, algumas ou todas as atividades, considerando os países em conjunto, para cada uma das rodadas.

Os dados sugerem que o grau de participação dos americanos e caribenhos é baixo. Em todas as rodadas, cerca de metade dos cidadãos está incluída na situação de não participação ou na participação em, no máximo, duas atividades. Entre os que participam, identifica-se uma tendência linear decrescente: à medida que aumenta o número de atividades, cai o percentual de indivíduos nelas envolvidas. Observa-se esse padrão em todas as rodadas, ininterruptamente.

Os resultados até aqui analisados permitem considerar que o ativismo político faz parte da vida da minoria dos americanos e caribenhos e que, dentre os participativos, o repertório de ações é limitado. Em ambas as dimensões, os padrões e tendências mostramse estáveis ao longo de todo o período analisado.

Tabela 6. Repertório de atividades participativas, por rodada13

\begin{tabular}{|c|c|c|c|c|c|c|c|c|c|c|c|c|c|c|c|}
\hline & \multicolumn{15}{|c|}{ Número de atividades participativas praticadas } \\
\hline & 0 & 1 & 2 & 3 & 4 & 5 & 6 & 7 & 8 & 9 & 10 & 11 & 12 & 13 & Média \\
\hline \multirow[t]{2}{*}{2004} & 9,0 & 24,6 & 20,3 & 16,3 & 10,9 & 7,3 & 4,4 & 3,1 & 1,9 & 1,0 & 0,7 & 0,4 & 0,1 & - & 2,78 \\
\hline & (723) & (1985) & (1634) & (1315) & (878) & $(590)$ & (356) & (248) & (155) & $(80)$ & (54) & (28) & (10) & & (8056) \\
\hline \multirow[t]{2}{*}{ 2006/7 } & 9,7 & 23,9 & 21,3 & 16,3 & 11,0 & 6,9 & 4,3 & 2,9 & 1,8 & 0,9 & 0,5 & 0,2 & 0,1 & - & 2,71 \\
\hline & $(2156)$ & (5296) & $(4715)$ & $(3608)$ & $(2440)$ & (1526) & (959) & (646) & (390) & (201) & (113) & (54) & (20) & & $(22125)$ \\
\hline \multirow[t]{2}{*}{2008} & 9,2 & 24,5 & 23,0 & 15,3 & 10,8 & 7,2 & 4,2 & 2,6 & 1,5 & 0,9 & 0,4 & 0,2 & 0,1 & - & 2,67 \\
\hline & $(851)$ & $(2276)$ & $(2137)$ & $(1424)$ & $(1003)$ & $(672)$ & $(388)$ & $(241)$ & (138) & $(86)$ & $(40)$ & (18) & $(10)$ & & $(9285)$ \\
\hline \multirow[t]{2}{*}{2010} & 10,5 & 27,5 & 21,7 & 14,7 & 9,9 & 6,3 & 3,9 & 2,4 & 1,5 & 0,9 & 0,5 & 0,2 & 0,01 & - & 1,68 \\
\hline & $(3168)$ & $(8307)$ & $(6551)$ & $(4425)$ & $(2975)$ & (1889) & $(1170)$ & $(718)$ & $(461)$ & $(260)$ & $(157)$ & (56) & (15) & & (32490) \\
\hline \multirow[t]{2}{*}{2012} & 10,4 & 27,3 & 21,8 & 14,8 & 9,8 & 6,1 & 4,0 & 2,5 & 1,5 & 0,9 & 0,5 & 0,3 & 0,1 & 0,01 & 2,56 \\
\hline & (3293) & (8653) & $(6906)$ & (4692) & (3104) & (1927) & (1262) & (802) & (482) & (291) & (153) & (89) & (33) & (12) & (32267) \\
\hline
\end{tabular}

Fonte: elaboração própria (2014), a partir dos dados do Barômetro das Américas.

13 Os percentuais são relativos apenas aos casos válidos. É aplicado um peso em cada análise a fim de que cada país contenha o mesmo número de casos, 1500. Em 2004, são 8056 casos válidos (53,7\%) e 6944 casos inválidos (46,3\%); em 2006/7, são 22125 casos válidos (67\%) e 10874 casos inválidos (33\%); em 2008 são 9285 casos válidos (25,8\%) e 26715 casos inválidos (74,2\%); em 2010 são 30153 casos válidos (77,3\%) e 8847 casos inválidos (22,7\%); e em 2012 são 31700 casos válidos (81,3\%) e 7300 casos inválidos (18,7\%). Na rodada de 2012, ocorre a inserção de uma variável ("assinatura de petições e abaixo assinados) e por isso há diferença quanto ao número total de atividades participativas em relação às demais rodadas. 


\section{Participação política em perspectiva comparada}

Até que ponto os patamares de participação de americanos e caribenhos se distinguem dos de cidadãos de outros países e regiões? Os seus graus de participação podem ser considerados baixos ou altos? Para responder a essas perguntas, é necessário ter um critério para distinguir o que é "pouca" e "muita" participação. A forma mais adequada de realizar essa análise é por meio da comparação.

$\mathrm{O}$ ideal seria contrapor a frequência das atividades participativas entre americanos e caribenhos à de cidadãos de maior número possível de países. Mas há escassez de dados de pesquisas de opinião que possam ser comparáveis, conforme alerta Norris (2002). Adicionalmente, nem todas as pesquisas de opinião que abarcam países variados possuem como principal interesse questões de natureza política e, especificamente, as relacionadas à participação. As pesquisas European Social Survey (ESS) e AfroBarometer (AB), porém, têm escopo semelhante ao do Barômetro das Américas: contêm vasta gama de variáveis sobre política, entrevistam cidadãos de variados países de um continente específico e comportam séries temporais que cobrem cerca de uma década. Por apresentarem essas características, são essas as pesquisas utilizadas nas análises comparadas a seguir.

As Tabelas 7 e 8 fornecem informações sobre a frequência das atividades participativas entre africanos (Tabela 7) nos anos 2002, 2004, 2006, 2008 e 2010; e entre europeus e israelenses (Tabela 8) nos anos de 2002-2003, 2005-2006, 2008-2009 e 2011-2012.

Comparando os dados dos cidadãos americanos e caribenhos com os demais, observa-se pouca diferença no comparecimento eleitoral. Entre os cidadãos dos três continentes, a média percentual varia entre $70 \%$ e $75 \%$.

Nota-se, contudo, bastante diferença no ativismo comunitário. Nesse caso, só é possível a comparação com os africanos: eles são muito mais ativos nessa arena, considerando vários indicadores. A frequência com que se assiste a reuniões na comunidade, por exemplo, é quase duas vezes e meia mais comum entre os africanos (64,8\%) que entre os americanos e caribenhos (26,9\%). Também há bastante diferença no contato com atores políticos e governamentais de âmbito local. Enquanto americanos e caribenhos apresentam médias próximas a 15,0\% - para "contato com atores políticos locais", 14,9\% e para "contato com vereadores e atores governamentais locais", 13,7\% - entre os africanos elas mostramse quase que duas vezes mais comuns: para "contato com ator governamental local", $27,3 \%$ e para "contato com conselheiros do governo local (vereadores)", 26\%.

Quanto à tentativa de convencer as pessoas sobre a escolha do voto, a comparação também só é possível entre americanos e caribenhos, de um lado, e africanos, de outro. Nesse caso, os percentuais são próximos, em torno de 35,0\% entre os primeiros e aproximadamente $30,0 \%$ entre os últimos.

O contato com parlamentares é uma atividade medida nas três pesquisas de opinião, embora a pergunta referente no ESS seja mais geral que nas demais, pois considera "contato com atores políticos e governamentais" conjuntamente. A despeito desse ponto, verificam-se percentuais próximos entre europeus e israelenses, e africanos (entre 10,0\% e 
15,0\%, aproximadamente), ao passo que entre americanos e caribenhos essa prática é um pouco menos usual $(8,0 \%)$.

A participação em protestos apresenta flutuações nos três casos analisados, mas é possível identificar diferenças. Esse tipo é menos comum entre europeus e israelenses (média de $6,5 \%$ em manifestações legais e 1,2\% em protestos ilegais, essa última medida presente apenas para a rodada de 2002) em comparação com os africanos, americanos e caribenhos, que têm percentuais próximos (em torno de 15\% para protestos). Já a assinatura de petições e/ou abaixo-assinados é questão tratada somente no ESS e no Barômetro das Américas e a diferença se mostra nítida: os europeus e israelenses apresentam quase o dobro de frequência nessa atividade (20,5\%) em relação aos americanos e caribenhos (11,5\%).

Por fim, ressalta-se a dificuldade para comparar as atividades participativas ligadas a partidos políticos. Nas três pesquisas utilizadas, essa questão é abordada, mas de três maneiras distintas, o que prejudica a comparação. Talvez o envolvimento partidário que mais requer dedicação e tempo seja a filiação partidária, que alcança baixa proporção entre os europeus e israelenses (5\%). Assistir a reuniões partidárias, atividade que não requer necessariamente a filiação, é prática comum para cerca de 15,0\% dos americanos e caribenhos. Já a simpatia partidária, talvez o laço mais frouxo entre cidadãos e partidos, alcança média de aproximadamente 60\% entre os africanos. Dadas as grandes diferenças de medidas, não parece pertinente comparar essa dimensão para os três casos.

Em síntese, os dados mostram que os africanos são os mais ativos na política comunitária. Já no contato com atores políticos e governamentais inseridos em esferas de poder nacional há poucas diferenças entre os cidadãos dos três continentes pesquisados, assim como entre os indicadores de participação na arena eleitoral (comparecimento eleitoral e convencer os outros sobre a escolha eleitoral). Em atividades políticas contestatórias, europeus e israelenses mostram-se os mais ativos em assinatura de petições, mas engajam-se com menor frequência que os africanos e os americanos e caribenhos em protestos.

Apesar das diferenças apontadas acima, pode-se constatar que, ao considerar o conjunto das atividades, a distribuição do ativismo político entre americanos e caribenhos não apresenta diferenças significativas em relação aos valores encontrados para os cidadãos dos outros continentes analisados. Em todos os públicos, a participação na política não é tarefa à qual se dedica a maior parte dos cidadãos. 
Tabela 7. Frequência e ranking de atividades participativas entre africanos (\%)

\begin{tabular}{|c|c|c|c|c|c|c|}
\hline Atividades & $2002 / 3$ & $2005 / 6$ & $2008 / 9$ & $2011 / 12$ & $\begin{array}{l}\text { Percentual } \\
\text { Médio }\end{array}$ & Ranking \\
\hline Votar & - & 74,3 & 70,0 & 76,0 & 73,4 & $1^{\circ}$ \\
\hline $\begin{array}{l}\text { Assistir a uma reunião } \\
\text { na comunidade }\end{array}$ & 66,1 & 66,2 & 64,0 & 63,0 & 64,8 & $2^{\circ}$ \\
\hline $\begin{array}{l}\text { Participar de reuniões de } \\
\text { campanha e de comícios } \\
\text { em eleições nacionais }\end{array}$ & - & - & - & 46,0 & 46,0 & $3^{\circ}$ \\
\hline $\begin{array}{l}\text { Convencer os outros } \\
\text { sobre a escolha do voto }\end{array}$ & - & - & - & 29,0 & 29,0 & $4^{\circ}$ \\
\hline $\begin{array}{c}\text { Contatar ator } \\
\text { governamental local }\end{array}$ & 27,3 & - & - & - & 27,3 & $5^{\circ}$ \\
\hline $\begin{array}{l}\text { Contatar conselheiros do } \\
\text { governo local [vereador (a)] }\end{array}$ & - & 25,1 & 27,0 & 26,0 & 26,0 & $6^{\circ}$ \\
\hline $\begin{array}{l}\text { Contatar alguma autoridade } \\
\text { de partido político }\end{array}$ & 17,3 & 15,0 & - & 16,0 & 16,1 & $7^{\circ}$ \\
\hline $\begin{array}{c}\text { Contatar alguma } \\
\text { autoridade de ministério }\end{array}$ & 14,4 & 11,2 & - & - & 12,8 & $8^{\circ}$ \\
\hline Participar de protestos & 14,3 & 13,5 & 13,0 & 9,0 & 12,4 & $9^{\circ}$ \\
\hline Contatar parlamentar & 11,8 & 10,3 & 12,0 & 13,0 & 11,8 & $10^{\circ}$ \\
\hline $\begin{array}{l}\text { Contatar ator } \\
\text { governamental regional }\end{array}$ & 7,0 & - & - & - & 7.0 & $11^{\circ}$ \\
\hline $\begin{array}{l}\text { Usar a força ou violência } \\
\text { para uma causa política }\end{array}$ & 4,2 & - & - & 4,0 & 4,1 & $12^{\circ}$ \\
\hline
\end{tabular}

Fonte: elaboração própria (2014), a partir dos dados do AfroBarometer. Disponível em: <www.afrobarometer.org> Acesso em: 10 ago. 2017. 
Tabela 8. Frequência percentual e ranking de atividades participativas entre europeus e israelenses ${ }^{14}$

\begin{tabular}{|c|c|c|c|c|c|c|c|}
\hline Atividades & 2002 & 2004 & 2006 & 2008 & 2010 & $\begin{array}{l}\text { Percentual } \\
\text { Médio }\end{array}$ & Ranking \\
\hline Votar & 75,1 & 71,1 & 72,7 & 72,2 & 70,9 & 72,4 & $1^{\mathrm{o}}$ \\
\hline $\begin{array}{l}\text { Comprar determinados } \\
\text { produtos por questões políticas }\end{array}$ & 26,3 & - & - & - & - & 26,3 & $2^{\circ}$ \\
\hline Assinar petição & 24,0 & 21,3 & 21,9 & 18,1 & 17,4 & 20,5 & $3^{\circ}$ \\
\hline $\begin{array}{c}\text { Boicotar determinados } \\
\text { produtos por questões políticas }\end{array}$ & 16,5 & 14,4 & 14,4 & 12,8 & 12,5 & 14,1 & $4^{\circ}$ \\
\hline $\begin{array}{l}\text { Contatar atores políticos } \\
\text { e governamentais }\end{array}$ & 16,2 & 14,2 & 14,0 & 12,3 & 12,2 & 13,8 & $5^{\circ}$ \\
\hline $\begin{array}{l}\text { Doar dinheiro a organização } \\
\text { ou movimento político }\end{array}$ & 8,5 & - & - & - & - & 8,5 & $6^{\circ}$ \\
\hline $\begin{array}{l}\text { Vestir ou usar um adesivo ou } \\
\text { broche de campanha política }\end{array}$ & 8,0 & 7,5 & 7,5 & 6,3 & 6,2 & 7,1 & $7^{\circ}$ \\
\hline $\begin{array}{c}\text { Participar de } \\
\text { manifestações legais }\end{array}$ & 7,7 & 7,4 & 5,8 & 5,8 & 5,6 & 6,5 & $8^{\circ}$ \\
\hline Ser filiado a partido político & 5,8 & 5,3 & 5,3 & 4,6 & 4,2 & 5,0 & $9^{\circ}$ \\
\hline $\begin{array}{c}\text { Participar de atividades } \\
\text { de protesto ilegais }\end{array}$ & 1,2 & - & - & - & - & 1,2 & $10^{\circ}$ \\
\hline
\end{tabular}

Fonte: Elaboração própria (2014), a partir dos dados do European Social Survey. Disponível em: <www.europeansocialsurvey.org >. Acesso em: 10 ago. 2017.

\section{Considerações finais}

Este artigo discutiu a participação política nas Américas e no Caribe. Mostrou-se que esse é um fenômeno multidimensional para o contexto analisado, no período temporal recente. Parece plausível propor que a ideia de demodiversidade - isto é, a coexistência pacífica ou conflituosa de diferentes modelos e práticas democráticas - deve estar no horizonte dos pesquisadores da área. Isso implica considerar menos fecundo um modelo restritivo de participação política, tal como o concebido por Milbrath (1965), que analisa as atividades participativas circunscritas exclusivamente à arena eleitoral.

A frequência das atividades participativas selecionadas indicou que apenas o voto é ação política comum na vida dos cidadãos. A grande maioria participa da escolha de seus representantes e governantes, independente do sistema eleitoral requerer a obrigatoriedade ou não do voto. Quanto à participação nos interstícios eleitorais, os dados mostram

14 Nas tabelas 7 e 8, considera-se apenas os casos válidos para gerar os percentuais. Os percentuais médios é resultado da soma de todos os percentuais por variável e a subsequente divisão pela quantidade de rodadas. 
que ela pode ser considerada baixa, levando-se em conta que mais da metade dos americanos e caribenhos variam da apatia política à participação em até duas atividades.

Para além do voto, ganha destaque o ativismo comunitário, o segundo tipo de participação mais frequente. Isso revela que a discussão e a resolução de questões comunitárias, locais e presentes no cotidiano, são, também, aspecto central para americanos e caribenhos, assim como para os africanos. Entretanto, esse é um tipo de participação política sobre o qual o interesse dos pesquisadores é recente e há ainda muita carência de dados a respeito. Pesquisas aplicadas em países desenvolvidos - como o European Social Survey e o World Values Survey, por exemplo - não tratam dessa dimensão, o que dificulta uma comparação mais ampla.

O Barômetro das Américas também não contém dados que permitam o teste empírico de teses importantes sobre o tema da participação política. Um exemplo é a tese da emergência do cidadão pós-materialista ou crítico, proposta por Inglehart (1990; 1993; 1997) e tratada também por Norris (1999; 2002).

Esses autores formulam a hipótese de que, especialmente nas sociedades altamente industrializadas ou desenvolvidas, a riqueza teria gerado mudanças na percepção de segurança econômica e aumento de capacidade cognitiva dos indivíduos, levandoos, paulatinamente, a modificarem seus valores. Assim, a predominância dos valores materialistas, que se caracterizam pela preocupação com a segurança econômica, estaria diminuindo, em contraposição ao aumento dos valores chamados pós-materialistas, que se fundam na defesa da autoexpressão (busca por mais direitos para as mulheres e os homossexuais, defesa do meio ambiente, por exemplo).

$\mathrm{Na}$ política também estariam ocorrendo mudanças. Seriam mais comuns atitudes e comportamentos críticos aos atores e instituições políticas tradicionais - como os políticos, os partidos e os sindicatos -, ao mesmo tempo em que ocorreria um aumento do apoio ao regime e aos valores democráticos, mas acompanhado de um ativismo político contestatório, como a participação em protestos, em boicotes, em ocupações de prédios públicos e privados e na assinatura de abaixo-assinados.

A investigação da possível emergência desses “cidadãos críticos” nos países incluídos na amostra do Barômetro das Américas não foi feita porque há pouca informação sobre o tipo de participação considerada contestatória. Espera-se, contudo, que o aprimoramento do questionário e a persistência do projeto por mais alguns anos permitam a investigação desse tema.

O trabalho contribui para o conhecimento da participação política no contexto das Américas e do Caribe, pois, a partir da inclusão de diversos países e rodadas de pesquisa, analisaram-se as principais tendências na participação política;identificaram-se as atividades mais frequentes e a nacionalidade dos cidadãos mais e menos participativos; descreveu-se a intensidade de participação e o quão ativos são americanos e caribenhos, comparados com cidadãos de outros continentes. Cobrir lacunas na literatura especializada com ampla quantidade de dados e de série temporal é a contribuição deste estudo para a literatura especializada. 


\section{Referências}

Barnes, Samuel et al. Political action: mass participation in five western democracies. London: Sage, 1979.

Booth, John; Seligson, Mitchell. Political participation in Latin America: an agenda for research. Latin America Research Review, v. 11, n. 3, 1976.

The legitimacy puzzle in Latin America: political support and democracy in eight nations. Cambridge: Cambridge University Press, 2009.

Borba, Julian. Participação política: uma revisão dos modelos de classificação. Sociedade e Estado, v. 27, n. 2, 2012.

BRADY, Henry. Political participation. In: Robinson, John. (Ed.). Measures of political attitudes. San Diego: Academic Press, 1999.

CORRAL, Margarita. (Mis)Trust in political parties in Latin America. Americas Barometer Insight, n. 2, 2008. Participation in meeting of political parties. Americas Barometer Insight, 2009a.

. Do parties listen to the people? Views from the Americas. Americas Barometer Insight, n. 12, 2009b.

FIALHO, Fabrício. Participação e desigualdade política: um exercício em teoria e método. 2008. 96 f. Dissertação (Mestrado em Ciência Política) - Departamento de Ciência Política, Universidade Federal de Minas Gerais, Belo Horizonte, 2008.

GERRING, John. What makes a concept good? A criterial framework for understand concept formation in the social science. Polity, v. 21, n. 3, 1999.

HAIR, Joseph et al. Análise multivariada de dados. Porto Alegre: Artmed, 2005.

HUNTINGTON, Samuel; NELSON, Joan. No easy choice: political participation in developing countries. Cambridge, MA: Harvard University Press, 1976.

INGLEHART, Ronald. Culture shift in advanced industrial society. Princeton: Princeton University Press, 1990.

. Democratização em perspectiva global. Opinião Pública, v.1, n.1,1993.

. Modernization and Postmodernization: cultural, economic and political change in 43 societies. Princeton: Princeton University Press, 1997.

JÖRESKOG, Karl Gustav; SÖRBOM, Darg. Advances in factor analysis and structural equation models. New York: University Press of America, 1979.

MILBRAITH, Lester. Political participation: how and why do people get involved in politics? Chicago: Rand McNally and Company, 1965.

NORRIS, Pippa. Introduction: the growth of critical citizens? In: (Ed.). Critical citizens: global support for democratic governance. Oxford: Oxford University Press, 1999.

. Democratic Phoenix: reinventing political activism. Cambridge: Cambridge University Press, 2002.

Political activism: new challenges, new opportunities. In: BOIX, Carles; STOKES, Susan. The oxford handbook of comparative politics. Oxford: Oxford University Press, 2007.

PASQUINO, Gianfranco. Curso de Ciência Política. Lisboa: Princípia, 2010.

PIZZORNO, Alessandro. Introducción al estudio de la participación política. In: PIZZORNO, Alessandro; KAPLAN, Marcos; CASTELLS, Manuel. Participación y cambio social em la problemática contemporánea. Buenos Aires: Siap-Planteos, 1975.

REIS, Fábio Wanderley. Cidadania, mercado e sociedade civil. In: MITRE, Antônio (Org.). Ensaios de teoria e filosofia politica em homenagem ao prof. Carlos Eduardo Baesse de Souza. Belo Horizonte: Departamento de Ciência Política-UFMG, 1994.

RENNÓ, Lúcio et al. Legitimidade e qualidade da democracia no Brasil: uma visão da cidadania. São Paulo: Intermeios; Nashville: LAPOP, 2011. 
RIBEIRO, Ednaldo; BORBA, Julian. Dimensões da participação política no Brasil. Teoria E Pesquisa, v. 20, n. 2, 2011.

TEORELL, Jan; TORCAL, Mariano; MONTERO, José Ramon. Political participation: mapping the terrain. In:VAN DETH, Jan; MONTERO, José Ramon; WESTHOLM, Anders (Org.). Citizenship and involvement in European democracies. New York: Routledge, 2007.

VAN DETH,Jan. Studying political participation: towards a theory of everything? towards a theory of everything? Paper presented at the ECPR Joint Sessions of Workshops, Grenoble, April 6-11th, 2001.

VERBA, Sidney; NIE, Norman. Participation in America: political democracy and social equality. New York: Harper \& Row Publishers, 1972.

VERBA, Sidney; NIE, Norman; KIM, Jae-on. Participation and political equality: a seven-nation comparison. New York: University of Chicago Press, 1987.

VERBA, Sidney; SCHLOZMAN, Kay; BRADY, Henry. Voice and equality: civic voluntarism in American politics. Cambridge; Massachusetts: Harvard University Press, 1995. 


\title{
The contours of political participation in the Americas and the Caribbean
}

\begin{abstract}
The article analyzes the political participation in American and Caribbean countries, using as data source the 2004, 2006-2007, 2008, 2010 and 2012 rounds of Americas' Barometer Surveys. The concept of political participation is discussed in order to propose its classification, taking into account several dimensions and describe its distribution and intensity. The frequency and intensity of political activism of the Americans and the Caribbean citizens with citizens of other continents are also compared. As main results, the article highlights the existence of five modalities of participation, verifies that vote and community activism are the most frequent activities identifies the nationality of the most and less participative citizens and shows that the levels of political activism between Americans and Caribbean and Europeans and Africans are closer.
\end{abstract}

Keywords: political participation, Latin America, Americas' Barometer.

\section{Los contornos de la participación política en las Américas y en el Caribe}

\section{Resumen}

El trabajo analiza la participación política en el continente americano y caribeño, utilizando como fuente de datos las ediciones de 2004, 2006-2007, 2008, 2010 y 2012 de la encuesta Barómetro de las Américas. El concepto de participación política es discutido, de manera a proponer una clasificación teniendo en cuenta varias dimensiones y describir su distribución e intensidad. También son comparadas la frecuencia y la intensidad del activismo político de los americanos y caribeños con las de los ciudadanos de otros continentes. Como principales resultados, el artículo destaca la existencia de cinco modalidades de participación, comprueba que el voto y el activismo comunitario son las actividades más frecuentes, identifica la nacionalidad de los ciudadanos más y menos participativos y muestra que el nivel de activismo político de los americanos y caribeños está cercano al de los ciudadanos de otros continentes, como europeos y africanos.

Palabras clave: participación política, América Latina, Barómetro de las Américas. 